\title{
PENINGKATAN PENGETAHUAN DAN KETRAMPILAN PETANI DALAM PEMBUATAN PAKAN SILASE DI KELOMPOK TANI RUKUN SEJAHTERA DESA BUALO KABUPATEN BOALEMO
}

\section{Improvement of Farmer's Knowledge and Skills in Making "Silase" In Rukun Sejahtera Tani Group, Bualo Village, Boalemo District}

\author{
Nurdin $^{1 *}$, Fitriah S. Jamin ${ }^{1)}$, Siswatiana R. Taha ${ }^{2)}$, Agustinus Moonti ${ }^{3)}$, \\ Rival Rahman ${ }^{1)}$ \\ ${ }^{1} J u r u s a n$ Agroteknologi Fakultas Pertanian Universitas Negeri Gorontalo, ${ }^{2}$ Jurusan \\ Peternakan Fakultas Pertanian Universitas Negeri Gorontalo, ${ }^{3}$ Jurusan Agribisni Fakultas \\ Pertanian Universitas Negeri Gorontalo \\ JI. Jendral Sudirman No. 6, Kota Gorontalo, 96128 \\ *Alamat korespondensi: nurdin@ung.ac.id
}

(Tanggal Submission: 14 Agustus 2020, Tanggal Accepted: 3 September 2020)

\begin{abstract}
ABSTRAK
Limbah pertanian, terutama jerami jagung (tebon) yang sangat melimpah dapat dimanfaatkan sebagai bahan baku pakan silase, tetapi masih banyak petani yang belum tahu dan belum bisa untuk membuat pakan silase tersebut. Kegiatan pengabdian masyarakat ini bertujuan untuk meningkatkan pengetahuan dan ketrampilan petani dalam pembuatan pakan silase di Kelompok Tani Rukun Sejahtera Desa Bualo Kecamatan Paguyaman Kabupaten Boalemo. Guna mencapai tujuan tersebut, maka metode pengabdian masyarakat yang digunakan adalah metode pelatihan dengan teknik ceramah dan tanya jawab, metode praktikum dan pendampingan kepada peserta, serta metode survei menggunakan instrumen kuisioner untuk menilai pengetahuan dan ketrampilan peserta dalam pembuatan pakan silase. Hasil yang diperoleh menunjukkan bahwa pelaksanaan kegiatan pelatihan dan praktek pembuatan pakan silase terbukti telah mampu memberikan peningkatan pada pengetahuan dan ketrampilan masyarakat, terutama petani tentang pakan silase dan pembuatannya. Tingkat pengetahuan petani tentang pakan silase sebelum pelatihan dilakukan mayoritas peserta pelatihan $(94,4 \%)$ tidak tahu dan sangat tidak tahu tentang pakan silase. Setelah mengikuti kegiatan pelatihan, maka mayoritas peserta pelatihan $(99,2 \%)$ sudah tahu dan sangat tahu tentang pakan silase. Tingkat ketrampilan petani setelah mengikuti praktek dan pendampingan pembuatan pakan silas, mayoritas $(90,4 \%)$ sudah bisa dan terampil dalam membuat pakan silase. Guna tindak lanjut dari kegiatan ini, maka perlunya pendampingan terus menerus kepada kelompok tani baik oleh penyuluh pertanian maupun perguruan tinggi agar limbah jagung dan limbah pertanian lainnya dapat dimanfaatkan sebagai pakan silase; dan (perlunya pengkayaan bahan pakan silase agar kandungan nutrisi pakan silase ini lebih lengkap (komplit).
\end{abstract}

Kata Kunci: Limbah, jagung, pakan, silase, molase.

\section{PENDAHULUAN}

Bualo merupakan salah satu desa agraris di wilayah Kecamatan Paguyaman Kabupaten Boalemo, Provinsi Gorontalo. Desa ini menjadi salah satu sentra produksi pertanian karena memiliki potensi untuk pengembangan pertanian yang cukup besar. Nurdin et al. (2009) melaporkan bahwa potensi lahan di wilayah Desa Bualo adalah sangat sesuai (S1) sampai sesuai marginal (S3) untuk tanaman jagung, kakao, kelapa dan hijauan makanan ternak dengan faktor pembatas 
kemiringan lereng, ketersediaan hara dan bahaya erosi. Sampai tahun 2020 , seluruh lahan pertanian di desa ini sudah dimanfaatkan untuk berbagai komoditas pertanian, baik tanaman pangan, hortikultura, perkebunan maupun peternakan.

Besarnya hasil pertanian dari desa ini tentu juga menghasilkan limbah pertanian yang sangat besar, utamanya limbah jagung. Luas pertanaman jagung di Desa Bualo sampai tahun 2019 mencapai 539,39 ha (BPS Kabupaten Boalemo, 2019) dan disumsikan menghasilkan jerami (tebon) jagung sebanyak 7.842 ton/ha (Jafrizal et al. 2018), maka diperoleh total limbah jagung sebanyak 4,2 juta ton. Namun, sangat sedikit limbah jagung tersebut yang dimanfaatkan dan lebih banyak dibiarkan begitu saja di lahan pertanian atau langsung dibakar. Padahal limbah jagung yang sangat melimpah ini dapat dimanfaatkan menjadi barang bernilai ekonomi tinggi diantaranya dengan menjadikannya pakan silase.

Pakan silase merupakan limbah pertanian yang diawetkan dalam keadaan segar (kandungan air 60-70\%) melalui proses fermentasi dalam silo (Kartasujana, 2001). Lebih lanjut McDonald et al. (2002) menyatakan bahwa silase adalah salah satu teknik pengawetan pakan pada kadar air tertentu melalui proses fermentasi mikrobial oleh bakteri asam laktat yang disebut ensilasi dan berlangsung di dalam tempat yang disebut silo. Teknologi silase dapat mengubah jerami jagung dari sumber pakan berkualitas rendah menjadi pakan berkualitas tinggi serta sumber energi bagi ternak (Trisnadewi et al. 2016). Selanjutnya, Keady (2005) menyatakan bahwa silase tanaman jagung dapat meningkatkan performa dari sapi penggemukan. Hal ini diduga karena kandungan nutrisi jerami jagung yang cukup tinggi. Silase jerami jagung dengan 20\% pollard menunjukkan kandungan nutrisi tertinggi dibanding perlakuan lainnya (Trisnadewi et al. 2016).

Salah satu kendala dan hambatan dalam pemanfaatan limbah jagung ini di Desa Bualo adalah petani belum mengetahui tentang pakan silase dan belum menguasai teknik pembuatan pakan silase tersebut. Hal ini cukup beralasan karena hasil komunikasi awal dengan petani setempat menunjukkan bahwa sampai saat ini belum pernah ada penyuluh pertanian atau insititusi lain yang memberikan pengetahuan dan ketrampilan tentang pembuatan pakan silase. Oleh karena itu, kegiatan dalam Program Pengembangan Desa Mitra (PPDM) di Desa Bualo menetapkan pembuatan pakan silase sebagai salah satu kegiatan utama pada tahun 2020 yang memasuki tahun pelaksanaan ke-2 program tersebut. Tujuan kegiatan ini adalah meningkatkan pengetahuan dan ketrampilan petani dalam pembuatan pakan silase di Kelompok Tani Rukun Sejahtera Desa Bualo Kecamatan Paguyaman Kabupaten Boalemo. Manfaat yang ingin dicapai dari kegiatan ini antara lain: meningkatnya pengetahuan dan ketrampilan petani dalam pembuatan pakan silase di Kelompok Tani Rukun Sejahtera, sehingga limbah jagung yang sangat melimpah tersebut dapat dioptimalkan menjadi pakan. Selain itu, kegiatan ini dilakukan untuk mengurangi dampak kebakaran lahan akibat pembakaran jerami jagung di lahan, sehingga potensi pencemaran lingkungan dengan adanya gas $\mathrm{CO} 2$ yang tinggi dapat diminimalisir.

\section{METODE KEGIATAN}

Kegiatan ini dilaksanakan pada bulan Juni 2020 di Desa Bualo Kecamatan Paguyaman Kabupaten Boalemo. Sasaran kegiatan ini adalah anggota Kelompok Tani Rukun Sejahtera sebanyak 25 orang dan peserta lain yang berasal dari masyarakat sekitar terutama aparat Desa Bualo yang juga memiliki ternak sapi. Pembuatan pakan silase ini dilakukan melalui kegiatan pelatihan dan pendampingan kepada anggota kelompok tani. Kegiatan ini didahului dengan pemberian materi pelatihan kepada peserta yang menjadi sasaran dan dilanjutkan dengan praktek pembuatan pakan silase. Sebelum dimulai pelatihan, terlebih dahulu 
dilakukan tes awal (pre test) tingkat pengetahuan peserta tentang pakan silase dengan metode survei menggunakan instrumen kuisioner.

Penilaian pengetahuan petani didasarkan pada lima item pertanyaan, yaitu: 1). Pengertian pakan silase; 2). Jerami dan limbah menjadi sumber pakan; 3). Pakan silase berasal dari limbah hasil pertanian; 4). Pakan silase memiliki kandungan nutrisi; dan 5). Pakan dapat bertahan 2 sampai 3 bulan. Peserta diminta memilih satu jawaban dengan cara mencentang atau melingkari pilihan jawaban huruf a, b, c, dan d pada instrumen. Pilihan jawaban peserta menunjukkan skor terendah sampai tertinggi. Jumlah peserta pelatihan adalah 25 orang (populasi), maka semua populasi karena <100 diambil sebagai sampel atau sampel jenuh (teknik non probability). Menurut Sugiyono (2013) sampel jenuh adalah teknik penentuan sampel dengan cara mengambil seluruh anggota populasi sebagai responden atau sampel. Setelah itu pemberian materi dengan metode ceramah dan tanya jawab.

Praktek pembuatan pakan silase dilakukan dengan pendekatan learning by doing. Sebelum praktek dilakukan, terlebih dahulu dikumpulkan bahan-bahan dan peralatan yang akan digunakn dalam pembuatan pakan silase. Bahan-bahan yang digunakan meliputi: limbah jagung, dedak, dekomposer (EM4), gula (molase) dan air. Sementara itu, peralatan yang digunakan terdiri dari: mensin pencacah (copper), bak fermentasi, ember, karung, drum dan sekop. Cara pembuatan paka silase meliputi: 1) Jerami jagung dicacah sampai berukuran 5-10 cm dengan tujuan untuk memadatkan jerami jagung saat penyimpanan, sehingga memudahkan terjadinya proses anaerob; 2) Jerami jagung yang sudah dicacah dikeringkan selama lebih kurang 6 jam untuk mengurangi kadar air, sehingga silase tidak membusuk; 3) Campurkan jerami jagung, molase, dedak, dan decomposer dengan cara diaduk secara merata; 4) Campuran tersebut selanjutnya dimasukkan dalam drum atau kotak penyimpanan dan harus ditutup rapat serta dipadatkan hingga tidak ada udara agar tidak terjadi pembusukan; 5) Setelah jerami jagung difermentasikan selama lebih kurang 3 minggu, maka hasilnya adalah silase jerami jagung dan selama masih tersimpan dengan baik jerami jagung bisa digunakan sampai 2 bulan.

Setelah pelatihan dan praktek pembuatan pakan silase dilaksanakan, maka dilakukan tes akhir (post test) tingkat pengetahuan peserta tentang pakan silase. Metode yang digunakan sama seperti tes awal, yaitu metode survei dengan menggunakan instrumen kuisioner kepada peserta pelatihan. Selain itu, pada sesi ini juga dilakukan penilaian ketrampilan peserta tentang pakan silase. Penilaian ketrampilan peserta didasarkan pada lima item pertanyaan, yaitu: 1). Bisa memilih bahan baku pakan silase; 2). Bisa melakukan pencacahan; 3). Bisa melakukan formulasi bahan pakan; 4). Bisa membuat dan memfermentasi pakan; dan 5). Bisa menghasilkan pakan silase sesuai standar.

Sampai akhir sesi praktek pembuatan pupuk organik, jumlah peserta masih sama sebanyak 25 orang (populasi), maka semua populasi diambil sebagai responden (sampel jenuh). Analisis data meliputi: (1) Analisis validitas dengan mengkorelasikan skor tiap butir dengan skor total yang merupakan jumlah tiap skor butir., (2) Analisis reliabilitas secara internal consistency dengan menganalisis konsistensi butir-butir pertanyaan yang ada., (3) Analisis tabel untuk mengetahui hubungan antar beberapa variabel. Data yang dikumpulkan disusun dalam bentuk tabel kemudian dianalisis secara deskriptif untuk mengetahui persentase responden terhadap pengetahuan tentang pupuk organik. Analisis dilakukan menggunakan bantuan software SPSS 23.

Tingkat pengetahuan dan ketrampilan peserta tentang pakan silase dianalisis dengan skor terhadap jawaban pertanyaan menggunakan alat ukur Skala Likert dan digambarkan dalam garis continuum. Jawaban peserta pada kuesioner diberi 
skor seperti berikut: jawaban a (sangat tahu dan sangat bisa) nilai 4, jawaban b (tahu dan bisa) nilai 3 , jawaban c (tidak tahu dan tidak bisa) nilai 2, dan jawaban d (sangat tidak tahu dan sangat tidak bisa) nilai 1. Interpretasi nilai skor dilakukan dengan menggunakan formulasi sebagai berikut:

$$
\begin{aligned}
& \text { Nilai maksimal } \\
& =\sum_{n}^{1} R \times \sum_{n}^{1} Q \times \text { Skor Tertinggi } \\
& \text { Nilai minimal } \\
& =\sum_{n}^{1} R \times \sum_{n}^{1} Q \times \text { Skor Terendah }
\end{aligned}
$$

Tingkat pengetahuan dan ketrampilan peserta adalah:

$$
\text { Nilai Total }=\frac{\sum \text { Skor }}{\text { Skor Tertinggi }} \times 100 \%
$$

Dimana: $\mathrm{R}=$ responden, $\mathrm{Q}=$ pertanyaan.

\section{HASIL DAN PEMBAHASAN}

\section{Peningkatan Pengetahuan Petani tentang Pakan Silase}

Peningkatan pengetahuan petani tentang pupuk organik dilakukan dengan cara memberikan pelatihan pembuatan pakan silase. Pelatihan tentang pakan silase dan cara pembuatannya dilakukan dengan ceramah dan tanya jawab yang tetap mengikuti protokol Covid-19 (Gambar 1). Kegiatan ini dilaksanakan di Aula Kantor Desa Bualo dengan peserta utama adalah anggota Kelompok Tani Rukun Sejahtera, dan peserta tambahan dari warga Desa Bualo lainnya, terutama perangkat desa yang juga berprofesi sebagai petani setempat.

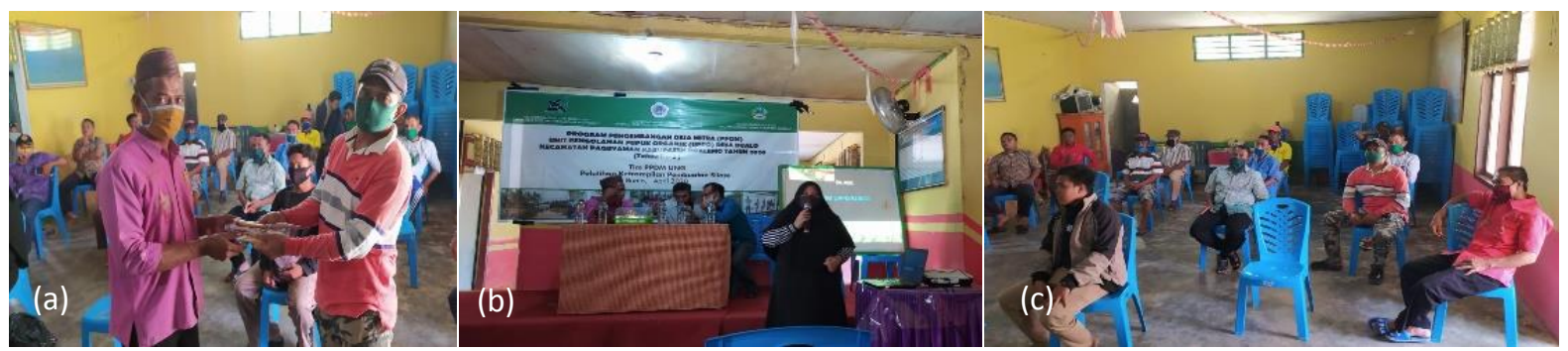

Gambar 1. Kegiatan Pelatihan Pembuatan Pakan Silase di Desa Bualo Kecamatan Paguyaman Kabupaten Boalemo; (a) Penyerahan Masker kepada Peserta oleh Kepala Desa Bualo, (b) Pemberian Materi Pelatihan, (c) Peserta Pelatihan menerapkan Protokol Covid-19.

Sebelum dan sesudah pelatihan melalui pemberian materi, maka dilaksanakan test awal dan test akhir tingkat pengetahuan peserta tentang pakan silase yang hasilnya disajikan pada Tabel 1, 2 dan Tabel 3. Hasil pengujian validitas instrumen pengetahuan awal dan akhir peserta tentang pakan silase menunjukkan bahwa instrumen yang digunakan untuk mengetahui tingkat pengetahuan awal dan akhir peserta tentang pakan silase di Desa Bualo Valid. Hal ini ditunjukkan oleh nilai korelasi mendekati 1 pada semua item yang diuji, yaitu antara 0,794 -0,980 untuk test awal dan antara 0,712-0,991 untuk test akhir dengan probabilitas korelasi yang sama dengan rata-rata sebanyak 0,000 (signifikan).

Tabel 1. Hasil Uji Validitas Instrumen Tingkat Pengetahuan Peserta Pelatihan

\begin{tabular}{llccccc}
\hline No & \multicolumn{1}{c}{ Korelasi Antara } & \multicolumn{2}{c}{$\begin{array}{c}\text { Nilai Korelasi } \\
\text { (Pearsons }\end{array}$} & \multicolumn{2}{c}{$\begin{array}{c}\text { Probabilitas } \\
\text { Korelasi } \\
\text { [sig.(2-tailed) }\end{array}$} & Kesimpulan \\
\cline { 3 - 5 } & Correlations) & Awal & Akhir & Awal & Akhir & \\
\hline 1 & Pengertian pakan silase & 0,870 & 0,984 & 0,000 & 0,000 & Valid \\
2 & Jerami dan limbah menjadi sumber pakan & 0,980 & 0,907 & 0,000 & 0,000 & Valid \\
3 & Pakan silase berasal dari limbah hasil pertanian & 0,980 & 0,991 & 0,000 & 0,000 & Valid \\
4 & Pakan silase memiliki kandungan nutrisi & 0,795 & 0,712 & 0,000 & 0,000 & Valid \\
5 & Pakan ini dapat bertahan 2-3 bulan & 0,794 & 0,991 & 0,000 & 0,000 & Valid \\
\hline
\end{tabular}


Hasil pengujian reliabilitas instrumen pengetahuan awal peserta tentang pakan silase menunjukkan bahwa nilai Cronbach's Alpha sebesar 0,824 dan setelah pelatihan nilai Cronbach's Alpha sebesar 0,821 (Tabel 2). Hal ini menunjukkan bahwa instrumen yang digunakan untuk mengetahui pengetahuan awal dan akhir peserta tentang pakan silase di Desa Bualo dianggap reliabel atau memenuhi syarat reliabilitas.

Tabel 2. Nilai Cronbach's Alpha Instrumen Tingkat Pengetahuan Peserta

\begin{tabular}{|c|c|c|}
\hline \multicolumn{3}{|c|}{ Tingkat Pengetahuan Peserta } \\
\hline \multicolumn{2}{|c|}{ Cronbach's Alpha } & $\mathrm{N}$ of items \\
\hline Awal & Akhir & \\
\hline 0,824 & 0,821 & 6 \\
\hline
\end{tabular}

Berdasarkan Tabel 3, mayoritas peserta sebelum pelatihan yang tidak tahu dan sangat tidak tahu terkait pakan silase masih sangat banyak dengan persentase sebesar $94.4 \%$. Sementara itu, peserta yang sudah tahu hanya sebesar 5,6\% tanpa ada peserta yang sudah sangat tahu. Setelah mengikuti pelatihan, peserta yang tahu dan sangat tahu sudah mencapai 99,2\%. Hanya tersisa 0,8\% saja yang tidak tahu tentang pakan silase.

Tabel 3. Persentase Jawaban Peserta tentang Pakan

\begin{tabular}{|c|c|c|c|c|c|c|c|c|c|c|}
\hline \multirow{3}{*}{ No } & \multirow{3}{*}{ Item Pertanyaan } & \multicolumn{8}{|c|}{ Persentase jawaban pengetahuan peserta (\%) } & \multirow{3}{*}{ Jumlah } \\
\hline & & \multicolumn{2}{|c|}{ STT } & \multicolumn{2}{|c|}{ TT } & \multicolumn{2}{|c|}{$\mathrm{T}$} & \multicolumn{2}{|c|}{ ST } & \\
\hline & & Awal & Akhir & Awal & Akhir & Awal & Akhir & Awal & Akhir & \\
\hline 1 & Pengertian pakan silase & 20 & - & 72 & - & 8 & 88 & - & 12 & 100 \\
\hline 2 & $\begin{array}{l}\text { Jerami dan limbah } \\
\text { menjadi sumber pakan }\end{array}$ & 20 & - & 72 & - & 8 & 88 & - & 12 & 100 \\
\hline 3 & $\begin{array}{l}\text { Pakan silase berasal dari } \\
\text { limbah hasil pertanian }\end{array}$ & 20 & - & 72 & - & 8 & 88 & - & 12 & 100 \\
\hline 4 & $\begin{array}{l}\text { Pakan silase memiliki } \\
\text { kandungan nutrisi }\end{array}$ & 12 & - & 84 & - & 4 & 92 & - & 8 & 100 \\
\hline 5 & $\begin{array}{l}\text { Pakan ini dapat bertahan } \\
2-3 \text { bulan }\end{array}$ & 28 & - & 72 & 4 & - & 88 & - & 8 & 100 \\
\hline & Rata-rata & 20,0 & - & 74,4 & 0,8 & 5,6 & 88,8 & - & 10,4 & 100 \\
\hline
\end{tabular}

Keterangan: STT = sangat tidak tahu, TT = tidak tahu, T = tahu, ST = sangat tahu.

Hasil evaluasi awal tingkat pengetahuan peserta pelatihan tentang pakan silase diperoleh skor pengetahuan awal peserta (Gambar 2), yaitu: skor total sebanyak 232 dengan skor tertinggi sebanyak 500 dan skor terendah sebanyak 125. Dengan demikian, maka rata-rata tingkat pengetahuan awal peserta tentang pakan silase di Desa Bualo Kecamatan Paguyaman Kabupaten Boalemo sebesar 46,4\% saja. Berdasarkan Garis
Continuum dapat diketahui bahwa pengetahuan awal peserta pelatihan termasuk dalam kategori tidak tahu tentang pakan silase. Secara ilmiah dan berdasarkan fakta tersebut, maka Tim PPDM dan pemateri pelatihan pembuatan pakan silase melakukan penajaman dan fokus terhadap peningkatan pengetahuan dan secara bertahap diikuti dengan peningkatan ketrampilan pembuatan pakan silase.

\begin{tabular}{|c|c|c|c|}
\hline STT & $\mathrm{TT}$ & 232 & $\mathrm{~T}$ \\
\hline & & & \\
\hline
\end{tabular}

Gambar 2. Garis Continuum Pengetahuan Awal Peserta tentang Pakan Silase

Selama kegiatan pelatihan, animo dan respon peserta pelatihan cukup tinggi yang ditunjukkan oleh banyaknya pertanyaan yang diajukan oleh peserta kepada pemateri. Pertanyaan yang paling menonjol adalah terkait tata cara pembuatan pakan silase dan daya simpan 
pakan silase jika nanti dibuat oleh petani. Setelah mendapat jawaban dari pemateri, maka optimisme peserta terhadap keberlanjutan kegiatan ini semakin nampak karena selain mudah membuatnya, juga ketersediaan bahan baku pakan silase yang banyak dan melimpah di Desa Bualo saat ini.

Hasil evaluasi akhir tingkat pengetahuan peserta pelatihan tentang pakan silase diperoleh skor pengetahuan akhir peserta (Gambar 3), yaitu: skor total sebanyak 386 dengan skor tertinggi sebanyak 500 dan skor terendah sebanyak 125 . Dengan demikian, maka rata-rata tingkat pengetahuan akhir peserta tentang pakan silase di Desa Bualo Kecamatan Paguyaman Kabupaten Boalemo sebesar $77,2 \%$ saja. Berdasarkan Garis Continuum dapat diketahui bahwa pengetahuan akhir peserta pelatihan termasuk dalam kategori sangat tahu tentang pakan silase.

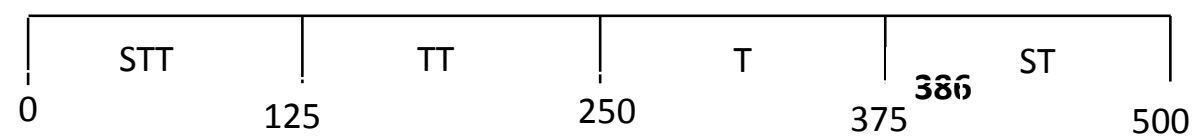

Gambar 3. Garis Continuum Pengetahuan Akhir Peserta tentang Pakan Silase

\section{Peningkatan Ketrampilan Petani dalam Pembuatan Pakan Silase}

Kegiatan peningkatan ketrampilan petani dilakukan melalui praktek dan pendampingan pembuatan pakan silase. Kegiatan ini diawali dengan praktek penggunaan sarana dan prasarana pembuatan pakan silase (Gambar 4). Kegiatan ini dilaksanakan di Rumah Kompos Milik Kelompok Tani Rukun Sejahtera dengan peserta utama adalah anggota kelompok tani, dan peserta tambahan dari warga Desa Bualo lainnya, terutama perangkat desa yang juga berprofesi sebagai petani setempat. Pembuatan pakan silase dengan memanfaatkan bahan baku lokal setempat yaitu: limbah jagung, dedak, dekomposer (EM4), molase dan air. Pembuatan pakan silase dengan melakukan proses fermentasi yang diikuti oleh peserta (anggota kelompok tani) dipandu oleh Tim PPDM dan Penyuluh Pertanian setempat (Gambar 5 dan 6). Hasil yang diperoleh cukup memuaskan dengan proses fermentasi yang berjalan dengan baik (Gambar 7). Selama proses fermentasi, dilakukan monitoring secara berkala untuk memperoleh hasil pakan silase yang sesuai standar.

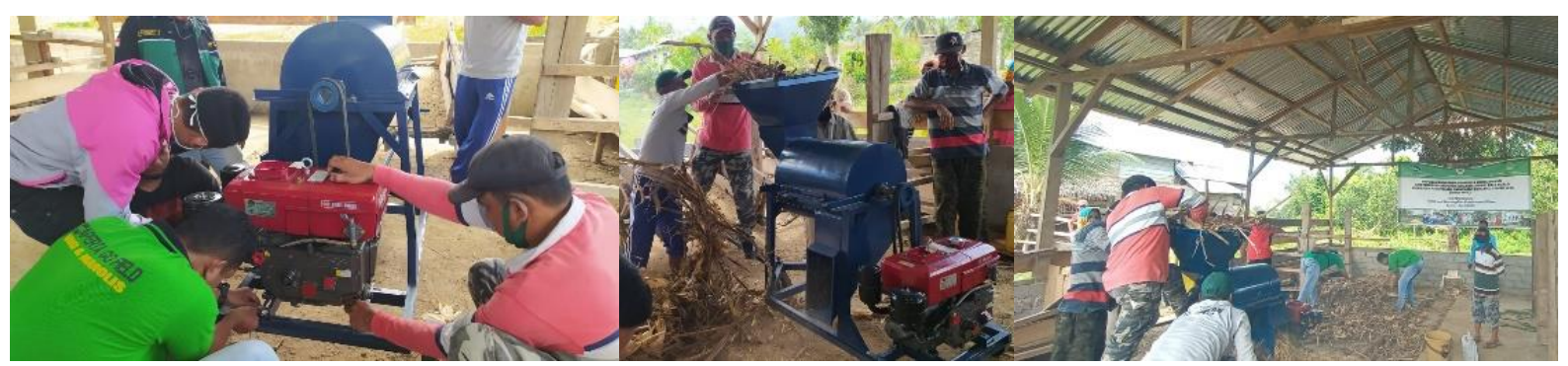

Gambar 4. Praktek Penggunaan Sarana dan Prasarana Pembuatan Pakan Silase di Desa Bualo Kecamatan Paguyaman Kabupaten Boalemo 


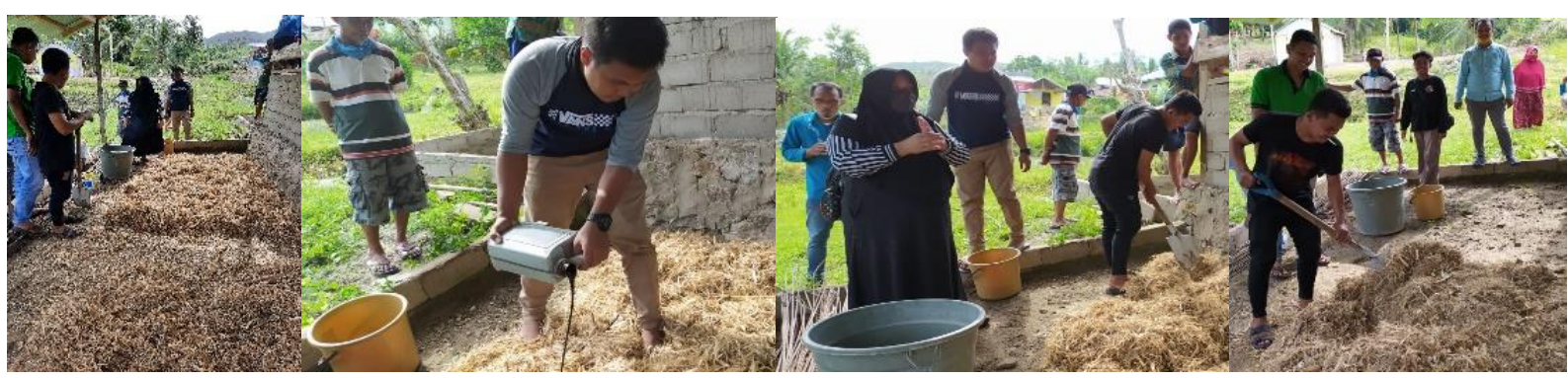

Gambar 5. Praktek Formulasi dan Pencampuran Bahan Pakan Silase di Desa Bualo Kecamatan Paguyaman Kabupaten Boalemo

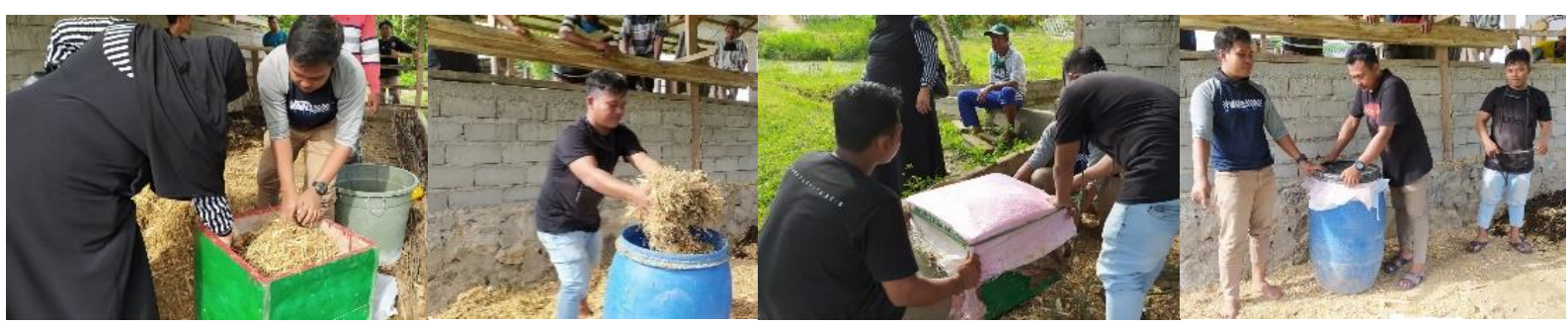

Gambar 6. Praktek Pemadataan dalam Media Drum atau Box Bahan Pakan Silase di Desa Bualo Kecamatan Paguyaman Kabupaten Boalemo

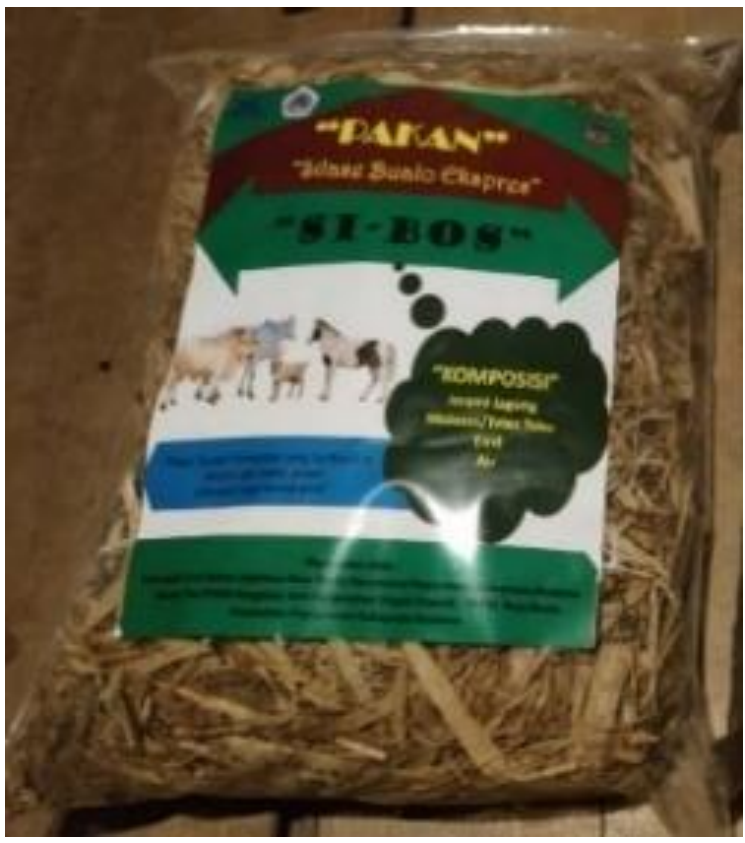

Gambar 7. Hasil Produksi Pakan Silase di Desa Bualo Kecamatan Paguyaman Kabupaten Boalemo

Pada sesi akhir praktek dan pendampingan pembuatan pakan silase ini dilakukan penilaian ketrampilan peserta tentang pembuatan pakan silase. Penilaian ketrampilan peserta didasarkan pada lima item pertanyaan, yaitu: 1). Bisa memilih bahan baku pakan silase; 2 ).
Bisa melakukan pencacahan; 3). Bisa melakukan formulasi bahan pakan; 4). Bisa membuat dan memfermentasi pakan; dan 5). Bisa menghasilkan pakan silase sesuai standar. Hasil evaluasi tingkat ketrampilan peserta dalam pembuatan pakan silase disajikan pada Tabel 4, 5, 6 dan Tabel 7. Hasil pengujian validitas instrumen ketrampilan peserta setelah mengikuti praktek dan pendampingan pembuatan pakan silase menunjukkan bahwa instrumen yang digunakan untuk mengetahui tingkat ketrampilan peserta tentang pakan silase di Desa Bualo Valid. Hal ini ditunjukkan oleh nilai korelasi mendekati 1 pada semua item yang diuji, yaitu antara 0,712 - 0,991 dengan probabilitas korelasi rata-rata sebesar 0,000 (signifikan).

Tabel 4. Hasil Uji Validitas Instrumen Tingkat Ketrampilan Peserta

\begin{tabular}{|c|c|c|c|c|}
\hline No & $\begin{array}{c}\text { Korelasi } \\
\text { Antara }\end{array}$ & $\begin{array}{c}\text { Nilai } \\
\text { Korelasi } \\
\text { (Pearsons } \\
\text { Correlatio } \\
\text { ns) }\end{array}$ & $\begin{array}{l}\text { Probabili } \\
\text { tas } \\
\text { Korelasi } \\
\text { [sig.(2- } \\
\text { tailed)] }\end{array}$ & $\begin{array}{c}\text { Kesimp } \\
\text { ulan }\end{array}$ \\
\hline 1 & $\begin{array}{l}\text { Bisa } \\
\text { memilih } \\
\text { bahan baku } \\
\text { pakan silase }\end{array}$ & 0,984 & 0,000 & Valid \\
\hline
\end{tabular}




\begin{tabular}{|c|c|c|c|c|}
\hline 2 & $\begin{array}{l}\text { Bisa } \\
\text { melakukan } \\
\text { pencacahan }\end{array}$ & 0,907 & 0,000 & Valid \\
\hline 3 & $\begin{array}{l}\text { Bisa } \\
\text { melakukan } \\
\text { formulasi } \\
\text { bahan } \\
\text { pakan }\end{array}$ & 0,991 & 0,000 & Valid \\
\hline 4 & $\begin{array}{l}\text { Bisa } \\
\text { membuat } \\
\text { dan } \\
\text { memferme } \\
\text { ntasi pakan }\end{array}$ & 0,712 & 0,000 & Valid \\
\hline 5 & $\begin{array}{l}\text { Bisa } \\
\text { menghasilk } \\
\text { an pakan } \\
\text { silase sesuai } \\
\text { standar }\end{array}$ & 0,991 & 0,000 & Valid \\
\hline
\end{tabular}

Hasil pengujian reliabilitas instrumen ketrampilan peserta tentang pakan silase menunjukkan bahwa nilai Cronbach's Alpha sebesar 0,828 yang lebih besar dari nilai 0,600 (Tabel 5). Hal ini menunjukkan bahwa instrumen yang digunakan untuk mengetahui ketrampilan peserta tentang pakan silase di Desa Bualo dianggap reliabel atau memenuhi syarat reliabilitas.

Tabel 5. Nilai Cronbach's Alpha Instrumen

\begin{tabular}{cc}
\multicolumn{2}{c}{ Tingkat Ketrampilan Peserta } \\
\hline \multicolumn{2}{c}{ Tingkat Ketrampilan Peserta } \\
\hline Cronbach's Alpha & N of Items \\
\hline 0,828 & 6 \\
\hline
\end{tabular}

Mayoritas peserta setelah praktek dan pendampingan pembuatan pakan silase yang bisa dan sangat bisa sudah mencapai 90,4\% (Tabel 6). Hanya tersisa 9,6\% saja yang tidak bisa tentang pakan silase, tanpa ada peserta yang sangat tidak bisa.
Tabel 6. Persentase Jawaban Peserta tentang Ketrampilan Pembuatan Pakan Silase Setelah Mengikuti Praktek dan Pendampingan

\begin{tabular}{|c|c|c|c|c|c|c|}
\hline \multirow[t]{2}{*}{ No } & \multirow{2}{*}{$\begin{array}{c}\text { Item } \\
\text { Pertanyaan }\end{array}$} & \multicolumn{4}{|c|}{$\begin{array}{c}\text { Persentase jawaban } \\
\text { peserta }\end{array}$} & \multirow[t]{2}{*}{ Jumlah } \\
\hline & & STB & TB & B & SB & \\
\hline 1 & $\begin{array}{l}\text { Pengertian } \\
\text { pupuk } \\
\text { organik }\end{array}$ & - & 12 & 76 & 12 & 100 \\
\hline 2 & $\begin{array}{l}\text { Penggunaan } \\
\text { pupuk } \\
\text { organik }\end{array}$ & - & 12 & 84 & 4 & 100 \\
\hline 3 & $\begin{array}{l}\text { Sumber } \\
\text { bahan } \\
\text { pupuk dari } \\
\text { limbah }\end{array}$ & - & 12 & 80 & 8 & 100 \\
\hline 4 & $\begin{array}{l}\text { Kandungan } \\
\text { hara pupuk } \\
\text { organik }\end{array}$ & - & - & 92 & 8 & 100 \\
\hline 5 & $\begin{array}{l}\text { Jenis-jenis } \\
\text { pupuk } \\
\text { organik }\end{array}$ & - & 12 & 80 & 8 & 100 \\
\hline \multicolumn{2}{|r|}{ Rata-rata } & - & $\begin{array}{l}9 . \\
6\end{array}$ & $\begin{array}{c}82 \\
.4\end{array}$ & $\begin{array}{l}8 . \\
0\end{array}$ & 100 \\
\hline
\end{tabular}

Keterangan: $\mathrm{STB}=$ sangat tidak bisa, $\mathrm{TB}=$ tidak bisa, $B=$ bisa, $S B=$ sangat bisa.

Hasil evaluasi akhir tingkat ketrampilan peserta pelatihan tentang pmbuatan pakan silase diperoleh skor total sebanyak 376 dengan skor tertinggi sebanyak 500 dan skor terendah sebanyak 125 . Dengan demikian, maka rata-rata tingkat ketrampilan peserta tentang pembuatan pakan seilase di Desa Bualo Kecamatan Paguyaman Kabupaten Boalemo sebesar $74,6 \%$. Berdasarkan Garis Continuum (Gambar 8) dapat diketahui bahwa ketrampilan peserta sudah termasuk dalam kategori sangat bisa dalam pembuatan pakan silase.

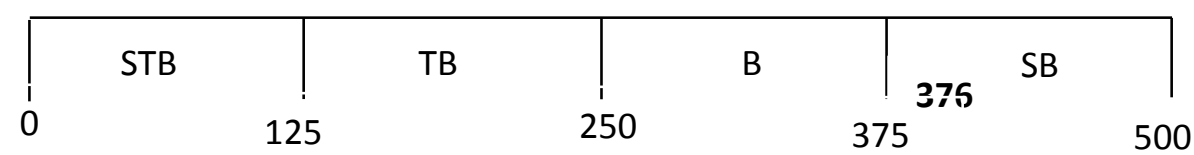

Gambar 8. Garis Continuum Ketrampilan Peserta dalam Pembuatan Pakan Silase 


\section{KESIMPULAN DAN SARAN}

Kesimpulan

Berdasarkan hasil kegiatan yang telah dilakukan sebelumnya, maka dapat disimpulkan hal-hal sebagai berikut:

1. Pelaksanaan program pengembangan desa mitra (PPDM) di Desa Bualo Kecamatan Paguyaman Kabupaten Boalemo melalui kegiatan pelatihan dan praktek pembuatan pakan silase terbukti telah mampu memberikan peningkatan pada pengetahuan dan ketrampilan masyarakat, terutama petani tentang pakan silase dan pembuatannya.

2. Tingkat pengetahuan petani tentang pakan silase sebelum pelatihan dilakukan mayoritas peserta pelatihan $(94,4 \%)$ tidak tahu dan sangat tidak tahu tentang pakan silase. Setelah mengikuti kegiatan pelatihan, maka mayoritas peserta pelatihan $(99,2 \%)$ sudah tahu dan sangat tahu tentang pakan silase.

3. Tingkat ketrampilan petani setelah mengikuti praktek dan pendampingan pembuatan pakan silas, mayoritas $(90,4 \%)$ sudah bisa dan terampil dalam membuat pakan silase.

\section{Saran}

Sebagai tindak lanjut dari kegiatan ini, maka saran yang perlu diajukan antara lain:

1. perlunya pendampingan terus menerus kepada kelompok tani baik oleh penyuluh pertanian maupun perguruan tinggi agar limbah jagung dan limbah pertanian lainnya dapat dimanfaatkan sebagai pakan silase;

2. perlunya pengkayaan bahan pakan silase agar kandungan nutrisi pakan silase ini lebih lengkap (komplit).

\section{UCAPAN TERIMA KASIH}

Terima kasih disampaikan kepada Kementrian Riset dan Teknologi/BRIN yang telah mendanai kegiatan pengabdian kepada masyarakat ini melalui Program Pengembangan
Desa Mitra (PPDM) tahun anggaran 2020 yang salah satu luarannya adalah artikel jurnal ini.

\section{DAFTAR PUSTAKA}

BPS Kabupaten Boalemo. 2019. Kabupaten Boalemo dalam Angka Tahun 2019. Badan Pusat Statistik Kabupaten Boalemo, Tilamuta.

Jafrizal, N. Kesumawati., \& R. Hayati. (2018). Inventarisasi potensi limbah pertanian dan peternakan dalam rangka mengembangkan usaha sayuran organik berbasiskan sumberdaya lokal di Kecamatan Selupu Rejang Kabupaten Rejang Lebong. Paper dipresentasikan pada Seminar Nasional Agroinovasi Spesifik Lokasi Untuk Ketahanan Pangan Pada Era Masyarakat Ekonomi ASEAN, Badan Penelitian dan Pengembangan Pertanian Kementrian Pertanian RI, Bandar Lampung, 19-20 Oktober 2018 (pp. 841-849). Bandar Lapung.

Keady, T. W. J. 2005. Ensiled maize and Whole Crop Wheat Forages For Beef and Dairy Cattle: Effects on Animal Performance. In: Silage Production and Utilization. Park, R.S. and M.D. Stronge (Eds.). Wageningen Academic Publ. The Netherlands. pp. $65-82$.

Nurdin, M. Baruwadi, F. Zakaria, R. Yusuf, D. A Rachim, Suwarno dan Darmawan. (2009). Penelitian dan Pengembangan Komoditas Unggulan Berdasarkan Potensi Sumberdaya Lahan melalui Analisis Kesesuaian Lahan dan Pewilayahan Komoditas Unggulan di Kabupaten Boalemo. Laporan Penelitian. Kerjasama Bappeda Kabupaten Boalemo dengan Pusat Kajian Pertanian Tropis (PKPT) Universitas Negeri Gorontalo, Tilamuta. 
Sugiyono. 2013. Metode Penelitian Pendidikan Pendekatan Kuantitatif, Kualitatif \& R\&D. Bandung: Alfabeta.

Trisnadewi, A. A. A. S., I G. L. O. Cakra., dan Suarna, I. W. 2017. Kandungan nutrisi silase jerami jagung melalui fermentasi pollard dan molases. Majalah IImiah Peternakan 20(2): 55-59. 